\title{
Ellipsis
}

Volume 44

Article 13

2017

\section{Brain Waves from an Alien's Radio}

Shaina Monet

Follow this and additional works at: https://scholarworks.uno.edu/ellipsis

\section{Recommended Citation}

Monet, Shaina (2017) "Brain Waves from an Alien's Radio," Ellipsis: Vol. 44 , Article 13.

DOI: https://doi.org/10.46428/ejail.44.13

Available at: https://scholarworks.uno.edu/ellipsis/vol44/iss1/13

This Poetry is brought to you for free and open access by the Department of English and Foreign Languages at ScholarWorks@UNO. It has been accepted for inclusion in Ellipsis by an authorized editor of ScholarWorks@UNO.

For more information, please contact scholarworks@uno.edu. 


\section{Brain Waves from an Alien's Radio \\ Shaina Monet}

\section{Vassar Miller Poetry Award Winner}

On antenna systems, Feynman notes: "Ours is one of the simplest possible ones; we can make them much more complicated, and by changing the phases in the various antennas we can send the beams in various directions and send most of the power in the direction in which we wish to transmit, without ever moving the antenna!"

— The Feynman Lectures on Physics, Vol. 1, Chapter 29-4, Two dipole radiators

Not sleeping under this window,

me, as the trees outside peek through lantern light

and bamboo slats.

the blind's bunched strings illume. sleeping troubles

me most at night, because I suspect

I have not met the right doctor yet the trouble

with thinking at night about the day I thought

I would never sleep again is how it felt,

how it feels still-life like now.

I am afraid and say so.

Because I cannot remember every body and every thing I have known, and done,

nor what they have done to me

and mine, my mind is likely to twist one

thing into another - twine so sound sews in two

syllables the way I've imagined a knot- Tonight, trouble sneaks in, asks me

Ben didn't hang himself

$$
\text { what if }
$$

from a tree?

the blind's bunched strings

illume. Because negation is a rope I can hang myself with, I have trouble in my body. nights inside the refrain

of proper nouns, troubled sleep and me, as troubling

as Ben who's passed himself and passed past 